\title{
PANDANGAN MUHAMMAD ASAD TENTANG SHARIAH
}

\author{
Ahmad Nabil Amir \\ Associate Research Fellow, \\ International Institute of Islamic Thought and Civilization
}

(ISTAC-IIUM)

No. 24, Persiaran Tuanku Syed Sirajuddin, Taman Duta, 50480 Kuala

Lumpur, Malaysia.

E-mail: nabiller2002@gmail.com

\begin{abstract}
Abstrak: This paper analyzed Muhammad Asad's views on Shariah (Islamic law). This was investigated from his thoughtful and broad understanding of its principle and underlying purpose. The essential understanding of the principle of shariah was analytically discussed in his works such as This Law of Ours and Other Essays, The Principles of State and Government in Islam and in his magnum opus The Message of the Qur'an. The finding shows that Muhammad Asad's discussion on shariah emphasized on its dynamic principle and relevance to contemporary practice and modern context of Islam. It set forth important framework towards reforming Islamic law by critically reconstructing and reprojecting its ideal in order to establish justice in implementing the law and in framing the ideal that underlie its purpose.
\end{abstract}

Keywords: Muhammad Asad, shariah, the practice of law, higher purpose of Islamic law

\section{MUKADDIMAH}

"The great mistake [of the Fundamentalists], is that most of these leaders start with the hudud, criminal punishment. This is the end result of the sharia [Islamic law], not the beginning. The beginning is the rights of people. There is no punishment in Islam which has no corresponding right."

1 Muhammad Asad, This Law of Ours and Other Essays (Kuala Lumpur: Islamic Book Trust, 1987). 
[Kesalahan (kaum Fundamentalis) yang fundamental adalab kebanyakan pemimpin ini bermula dengan budud, bukuman jenayah. Ini adalah hasil akbir dari sharia (perundangan Islam), bukan permulaan. Permulaannya adalab bak-bak manusia. Tiada penghukuman dalam Islam tampa pemberian bak yang sama]

Tulisan ini membincangkan pemikiran dan pandangan hukum Muhammad Asad dan kefahaman yang digarap dari perbincangannya tentang landas moral dari syariat dan falsafah dan implikasinya yang luas. Ia mengungkapkan tentang kerangka pemikiran hukum dan nilai dan cakupannya yang luas yang menzahirkan prinsip dan idealisme maqasid dan nilai syar'i yang mendasar.

Dasar kefahaman dan pemikiran hukum dan syariat yang universal ini diungkapkan dalam bukunya This Law of Ours and Other Essays dan Sabih al-Bukhari: The Early Years of Islam yang menghuraikan ruang lingkup dan implikasi yang praktikal dari Undang-Undang Islam. Ia melontarkan aspirasi dan pandangan yang meyakinkan tentang nilai dan kekuatan hukum yang signifikan dan pengaruhnya yang ideal:

\begin{abstract}
"The practical goal of the Islamic shari'ah is the construction of social conditions in which all individuals will find equal opportunities for their spiritual and material development. This practical, social purpose of the shari'ah gives the Muslims the moral right to strive for its establishment in the world."
\end{abstract}

Idea tentang Shari'ah yang digarap dalam bukunya yang lain The Principles of State and Government in Islam ${ }^{3}$ turut melakarkan pandangan dan hujah yang signifikan yang dizahirkan bagi menangani kekeliruan dan kesalahfahaman tentang Shari'ah oleh masyarakat Islam. Menurutnya, Shariah jika diterapkan, dapat membantu mengurangkan ketegangan yang ditimbulkan oleh pelbagai aliran mazhab yang rencam. Penafsiran yang ideal tentang hukum dan idea shariah ini berakar dari nas yang fundamental dan qat'i dari al-Qur'an dan sunnah yang membentuk pemahamannya tentang syariah yakni, apa "yang telah digariskan dalam perintah al-Qur'an dan ditambah (atau, sebenarnya, diperincikan dan ditunjukkan) oleh Nabi Muhammad (saw) dalam tuntunannya yang kita

\footnotetext{
${ }^{2}$ Muhammad Asad, Sabih al-Bukhari: The Early Years of Islam (Kuala Lumpur: Islamic Book Trust, 2002), 361.

3 Muhammad Asad, The Principles of State and Government in Islam (Berkeley and Los Angeles, California: University of California Press, 1961), 3.
} 
panggil sunnah [that which has been provided in the ordinances of the Qur'an and supplemented (or, rather, detailed and exemplified) by the Prophet Muhammad (saw) in the body of teachings which we describe as his sunnah]. ${ }^{4}$

\section{PENGERTIAN SYARIAT}

Perkataan syariat berasal dari bahasa Arab dari rumpun kata sh-r-a (jalan membawa ke tempat minum, untuk merencanakan atau memanifestasi, undang-undang) yang tercantum sebanyak lima kali dalam al-Qur'an dalam 4 bentuk, shara'a (2 kali), shurra'an (sekali), shir'atan (sekali), sharíatin (sekali). Asad menerangkan maksud syariat dari kefahaman asas yang dipegang mazhab fuqaha dengan menukil pandangan Ibn Hazm (994-1064), sebagai berikut: "The Shari'ah in its entirely refers either to obligatory acts [fard], the omission of which constitutes a sin; or to forbidden acts [haram], the commission of which constitutes a sin; or to allowed acts [mubah], the commission or omission of which does not make man a sinner." 5

Takrif syariat yang lebih mendalam dilakarkan oleh Asad dalam bukunya This Law of Ours, " dengan makna "the way to a watering place" (from which men and animals derive the element indispensable to life) and is used in the Qur'an to denote a system of laws necessary for a community's social and spiritual welfare ${ }^{7}$, dan melanjutkan tentang implikasi dari kefahaman ini "since water is indispensable for all organic life, this term has in time come to denote a 'system of laws', both moral and practical, which shows man the way towards spiritual fulfillment and social welfare". ${ }^{8}$

Pentafsiran shariah secara teknikal yang dilakarkan dalam bukunya This law of Ours and Other Essays menguraikan maksud dan kefahamannya yang mendalam sebagai "the elixir for humanity, the Right Way marked out in the commandments of God and His Apostle: the law of Islam" ?

\footnotetext{
${ }^{4}$ Ibid.

${ }^{5}$ Muhammad Asad, The Principles of State and Government in Islam (Berkeley and Los Angeles, California: University of California Press, 1961), 13.

6 Muhammad Asad, This Law of Ours and Other Essays (Kuala Lumpur: Islamic Book Trust, 1987), 41.

7 Muhammad Asad, The Message of the Qur'an (Gibraltar: Dar al-Andalus, 1980), 5:48, $223, \mathrm{ft} 66$.

8 Ibid; 45:18, 1043, ft 18.

9 Muhammad Asad, This Law of Ours and Other Essays (Kuala Lumpur: Islamic Book
} 
Perbahasan teknikal yang lebih meluas tentang makna syariah juga dapat ditinjau dari kupasannya pada surah 5:48 dan 45:18 dari tafsirnya yang muktabar The Message of the Qur'an: "Kepada setiap darimu Kami telah menetapkan syariat dan cara hidup [yang berbeza]" (5:48).

Menjelaskan pengertian ayat ini Asad menerangkan: "Ekspresi "setiap darimu" menunjukkan beraneka rupa masyarakat dari mana umat manusia dibentuk. Istilah shir'ah (atau shari'ah) menunjukkan, dari segi literal, "jalan ke mata-air" (dari mana manusia dan haiwan mengambil unsur yang tak dapat tidak kepada kehidupan mereka), dan digunakan dalam al-Qur'an untuk menunjukkan sistem hukum yang perlu bagi kebajikan sosial dan spiritual masyarakat. Istilah minhaj, sebaliknya, menunjukkan "jalan yang terbuka", biasanya dalam pemahaman yang abstrak: yakni, "satu cara hidup". Istilah shir'ah dan minhaj lebih terbatas dalam maksudnya dari istilah din, yang merangkumi tidak hanya hukum yang berkait dengan agama tertentu tetapi juga kebenaran spiritual yang mendasar, tak berubah yang, menurut al-Qur'an, telah diajarkan oleh setiap seorang dari pesuruh Tuhan, sementara isi hukum yang tertentu (shir'ah atau shariah) yang disebarkan melalui mereka, dan cara hidup (minhaj) yang dianjurkan oleh mereka, berbeza mengikut keperluan masa dan perkembangan budaya setiap masyarakat. "Kesatuan dalam kepelbagaian" ini sering ditekankan dalam al-Qur'an (e.g., dalam kalimah pertama dari 2:148, dalam 21:92-93, atau dalam 23:52 ff.). Kerana kebolehpakaian yang universal dan keutuhan tekstual dari ajarannya dan juga kenyataan bahawa Nabi Muhammad (saw) adalah "penutup sekalian nabi", i.e., yang terakhir dari mereka (lihat 33:40) - al-Qur'an mewakili titik puncak dari semua wahyu dan menawarkan jalan yang terakhir, sempurna kepada pemenuhan spiritual." 10

Dan hujah ini diperkukuh dalam kupasannya pada ayat 45:18, yang berbunyi: "Kami telah tetapkan engkau di atas jalan dengan mana tujuan [keimanan] dapat dipenuhil". Asad menerangkan: "Makna literal, "di atas jalan dari tujuan [keimanan]": lihat nota 15 di atas. Ia harus diingat bahawa makna literal dari istilah shariah adalah "jalan kepada sumberair", dan mengingat air adalah sangat diperlukan untuk semua kehidupan organik, istilah ini telah dalam peredaran waktu menandakan suatu "sistem undang-undang", baik moral dan praktikal, yang menunjukkan manusia jalan ke arah pemenuhan spiritual dan kebajikan sosial: justeru,

Trust, 1987), 41.

${ }^{10}$ Muhammad Asad, The Message of the Qur'an (Gibraltar: Dar al-Andalus, 1980), 5:48, 223, ft 66 . 
"syariat agama" dalam pengertian yang paling luas dari istilah tersebut. (Lihat dalam hubungan ini nota 66 pada bahagian kedua dari 5:48.) ${ }^{11}$

\section{TAKLIFF DAN HAQQ}

"No duty (takliff) is ever imposed on man without bis being granted a corresponding right (Haqq)"12

[tiada kewajipan yang dibebankan ke atas manusia tanpa dia diberikan hak yang sama]

Menurut Asad, undang-undang syariah menyentuh setiap aspek dari kewujudan manusia dan merupakan nafas-dari kehidupan Islam "Shari'ah touches every aspect of human existence and is the life-breath of Islam." 13

Dalam hal ini beliau menekankan dasar moral yang dimaksudkan dari penegakkan hukum dan undang-undang Had, qisäs dan ta'šir, yang bertujuan menjamin keselamatan sosial dan kemaslahatan umum berasaskan nilai dan tanggungjawab sosial yang seimbang di mana "Tiada penghukuman dalam Islam tanpa pemberian hak yang sama" sebagai prasyaratnya yang penting, seperti tercatat dalam tafsirnya:

"punishment intended for social security", applicable only within the context of an already existing, fully functioning social security scheme, and in no other circumstances." 14

Dan hujah yang diketengahkan ini menzahirkan aspirasi dan citacita Islam yang sebenar dari penegakkan hukum yang memperjuangkan keadilan dan prinsip musawah dan pembentukan tata sosial yang ideal:

Qisas has been often and erroneously treated as retaliation rather it is a "just retribution" that all classical commentators consider it synonymous with Musäwah (making a thing equal [to another thing]) "in this instance, making the punishment equal (or appropriate) to the crime." 15

\footnotetext{
${ }^{11}$ Ibid.

12 Ibid; 5:38, 218, ft. 48.

13 Muhammad Asad, This Law of Ours and Other Essays (Kuala Lumpur: Islamic Book Trust, 1987), 20.

${ }^{14}$ Muhammad Asad, The Message of the Qur'an (Gibraltar: Dar al-Andalus, 1980), 5:38, 218, ft. 48.

15 Ibid; 2:178, hh. 71-72, ft. 147.
} 
"The objective of qisas is the protection of the society and not the revenge; and accordingly the implementation of Islamic legal punishments is to safeguard the community or a society as a whole." 16

\section{Shariah yang Dimusykilkan}

"A thousand years of theology and canonical jurisprudence have made the simplicity of Islam entirely illusonary and the presence of various schools of thought put a common person into confusion" 17

Menurut Asad, dasar pokok dari syariat agama ini bersifat banifiyah sambah [ringan dan mudah], dan ritual agama ini telah dipersulit oleh istinbat-istinbat hukum yang kompleks yang membingungkan dari peraturan-peraturan fiqh kepada pemahaman awam: "including the juristic regulations of various jurists (fuqaba) in Shari' $a b$ has made Shari' $a b$ inaccessible to the understanding of common man. ${ }^{18}$

Kerana pada asasnya hanya nas al-Qur'an dan sunnah sahaja yang membentuk syariat yang sepenuhnya, seperti dijelaskan dari hujahnya yang meyakinkan tentang hukum syar'i: "The nass ordinances of the Qur'an and Sunnah, comparatively few as they are, constitute the sumtotal of the Shari'ah in its true and eternal sense." ${ }^{19}$

Dan ini menyebabkan wahyu dari syariah yang sedari awalnya diturunkan sebagai landasan hidup sekonyong-konyong menjadi perbahasan akademik yang terpisah dari kenyataan dan persoalan hidup sehari-hari:

"Making Shari'ah the preserve of "specialised scholars", instead of being a way of life became a merely academic affair and thus its practicability became an illusion." 20

Maksud syariat yang sambah dan banifiyyah yang menekankan keringanan hukum hakam agama ini, dipaparkan dalam tafsiran Asad pada surah al-Maidah [5:101] yang menggariskan prinsip asas dari syariat

\footnotetext{
16 Ibid; 2:179, h. 73, ft. 151.

${ }^{17}$ Muhammad Asad, This Law of Ours and Other Essays (Kuala Lumpur: Islamic Book Trust, 1987), 19.

${ }^{18} \mathrm{Ibid} ; \mathrm{pp} .20 \mathrm{f}$.

${ }^{19} \mathrm{Ibid} ; 65$.

${ }^{20}$ Ibid; 22.
} 
dan kesulitan yang ditimbulkan dari peraturan hukum yang memperberat dan memusykilkan dengan istinbat-istinbat fiqh:

"Wahai orang-orang yang telah mencapai keimanan! Jangan bertanya tentang perkara yang jika diterangkan kepadamu [dari hal hukum], mungkin menyebabkan kesulitan bagimu" (5:101)

Asad menjelaskan pandangan mufassir dan fuqaha besar seperti Ibn Hazm al-Zahiri yang menolak pembebanan dan pemberatan hukum syar'i yang mudah: "Ayat ini berkait secara langsung dengan ayat 99: "Tidak diwajibkan bagi Rasul lebih dari menyampaikan pesan." Dibaca dalam hubungan dengan kalimah, "Hari ini Aku telah sempurnakan syariat agamamu bagimu" (tertera dalam ayat 3 dari surah ini), pernyataan di atas membayangkan bahawa orang-orang beriman tidak harus cuba untuk menyimpulkan hukum "tambahan" dari perintah yang dengan jelas ditetapkan dengan demikian oleh al-Qur'an atau oleh Nabi (saw), kerana ini "mungkin menyebabkan kesulitan bagimu - yakni, mungkin (sebagaimana telah sesungguhnya terjadi selama berabad) mengenakan beban tambahan ke atas orang-orang beriman melewati dan mengatasi apa jua yang telah ditentukan dalam hal hukum dalam al-Qur'an atau dalam perintah yang sahih dari Nabi (saw). Berdasarkan kepada ayat ini, sebahagian dari ulama Islam yang terkemuka telah menyimpulkan bahawa Syariat Islam, secara keseluruhannya, merangkumi tak lebih dari perintah yang jelas yang datang dari perkataan yang sudah-jelas (zabir) dari al-Qur'an dan perintah Nabi (saw), dan bahawa, alhasilnya, ianya tidak dibenarkan untuk memanjangkan ruang lingkup dari ordinan yang sudah-jelas itu melalui metode istinbat yang subjektif. (Perbincangan yang paling tercerah tentang permasalahan ini ditemui dalam Pengenalan kitab al-Muballa oleh Ibn Hazm, jil. I., 56 ff.) Ini, tentunya, tidak menghalang masyarakat Islam dari mengembangkan, bila-bila perlu, sebarang jumlah dari perundangan tambahan, temporal mengikut semangat al-Qur'an dan ajaran Nabi (saw): tetapi ia harus difahami dengan jelas bahawa perundangan tambahan itu tidak boleh dianggap sebagai membentuk bahagian dari Syariat Islam (shari'ab) itu sendiri." 21

\section{PRINSIP KEBEBASAN}

"Those who hope to nurture genuine religiosity should first establish

${ }^{21}$ Muhammad Asad, The Message of the Qur'an (Gibraltar: Dar al-Andalus, 1980).

19 Ahmad Nabil Amir - Pandangan Mubammad Asad tentang shariah 
liberty" - 22

(kalangan yang berhasrat memupuk keagamaan yang sejati harus pertama sekali memastikan tertegaknya kebebasan)

Prinsip kebebasan yang merupakan salah satu aspek penting dari maqasid syar'i ditekankan oleh Asad dalam tafsirannya pada ayat 2:256 (al-Baqarah) "Tidak harus ada paksaan dalam urusan agama" (La ikrah fi al-din) yang mengungkapkan konsep kebebasan agama (al-burriyyah aldiniyyah), dan implikasi semantik dari konsep din atau moral law dan menegaskan nilai dan implikasi hukum yang signifikan dari ayat ini: "there shall be no coercion in matters of faith" (tidak ada paksaan dalam hal yang menyangkut keyakinan)

"The term din denotes both the contents of and the compliance with a morally binding law; consequently, it signifies 'religion' in the widest sense of this term, extending over all that pertains to its doctrinal contents and their practical implications, as well as to man's attitude towards the object of his worship, thus comprising also the concept of 'faith.' The rendering of it as 'religion,' 'faith,' 'religious law' or 'moral law' ...depends on the context in which this term is used - On the strength of the above categorical prohibition of coercion (ikrab) in anything that pertains to din faith or religion, all Islamic jurists (fuqaba), without any exception, hold that forcible conversion is under all circumstances null and void, and that any attempt at coercing a nonbeliever to accept the faith of Islam is a grievous sin: a verdict which disposes of the widespread fallacy that Islam places before the unbelievers the alternative of conversion or the sword." 23

[istilah din menunjukkan kedua-duanya isi dari dan kepatuhan terhadap hukum moral yang mengikat; alhasilnya, ia menandakan 'agama' dalam pengertian yang paling luas dari istilah ini, menjangkau ke atas semua yang berkait dengan muatan doktrinnya dan implikasi praktisnya, dan juga kepada sikap manusia terhadap objek pendewaannya, justeru merangkumi juga konsep tentang 'kepercayaan.' Terjemahan terhadapnya sebagai 'agama,' 'kepercayaan,' 'syariat agama' atau 'hukum moral'...bergantung kepada konteks di mana istilah ini digunakan Tentang kekuatan larangan yang mutlak di atas terhadap paksaan (ikrah) dalam apa jua yang berkait dengan din kepercayaan atau agama, semua

\footnotetext{
${ }^{22}$ Mustafa Akyol, Islam Without Extremes: A Muslim Case for Liberty (New York: W.W. Norton \& Company, Inc., 2011).

${ }^{23}$ Muhammad Asad, The Message of the Qur'an, 2:256.
} 
ahli fekah (fuqaha), tanpa sebarang pengecualian, berpegang bahawa penukaran agama dengan kerahan dalam semua keadaan adalah terbatal dan tidak sah, dan bahawa sebarang percubaan untuk memaksa orang tidak-beriman untuk menerima agama Islam adalah dosa yang besar: keputusan yang melupuskan semua salahtanggapan yang meluas bahawa Islam meletakkan alternatif kepada orang tidak beriman antara memeluk Islam ataupun pedang]. ${ }^{24}$

Tafsiran ini turut diangkat dalam syarahnya pada Sabih al-Bukhari, Kitab al-Iman tentang prinsip kebebasan agama yang diungkap dalam hadith al-Bukhari:

"Nothing is further from truth than this: for the use of force in those early days of Islam had for its object not the spreading of beliefs, but the establishment of certain social conditions regarded as beneficial to all. As to beliefs, the liberty of conscience is authoritatively laid down in the Qur'an: "There is no compulsion in religion" (Surab ii. 256) ${ }^{25}$

Dan pandangan ini turut diperkuat oleh al-Tabari yang mengungkapkan pemahaman yang sama dalam tafsirnya yang menekankan asas kebebasan beragama dan menggariskan kekuatan idealisme Islam yang memungkinkan penerimaannya yang lahir dari keyakinan dan bukan dengan kekerasan dan paksaan: "sungguh telah jelas antara kebenaran dan kebatilan. Dan telah jelas sudah sisi kebenaran bagi para pencari kebenaran. Dan kebenaran ini telah terbedakan dari kesesatan. Sehingga tidak perlu lagi memaksa para ahli kitab dan orangorang kafir yang dikenai jizyah untuk memeluk agama Islam, agama yang benar. Dan orang-orang yang berpaling dari kebenaran ini setelah jelas baginya, biarlah Allah yang mengurusnya. Sungguh Allahlah yang akan mempersiapkan hukuman bagi mereka di akhirat kelak". ${ }^{26}$

Pandangan yang sama dari prinsip kebebasan iktikad ini disuguhkan dalam komentarnya pada ayat 9:6 (al-Tawbab) yang berbunyi: "kirimkan dia ke tempat yang dia dapat merasa selamat: ini, kerana mereka [mungkin] kaum yang [berdosa hanya kerana mereka] tidak mengetahui [kebenaran]."

\footnotetext{
24 Ibid; 2:256.

${ }_{25}$ Muhammad Asad, Sabih al-Bukhari: The Early Years of Islam (Kuala Lumpur: Islamic Book Trust, 2002), 361.

${ }^{26}$ Al-Tabari, Jami' al-Bayan 'an Ta'wil Ay al-Qur'an (Bayrut: Dar Ihya' al-Turath al-'Arabi, 2001).
}

21 Ahmad Nabil Amir - Pandangan Mubammad Asad tentang shariah 
Asad mengulas: "Lit., "his place of security" (ma'manabu) - Makna literal, "tempatnya yang selamat" (ma'manahu)- i.e., "biarkan dia kembali ke tanah airnya" (Razi), yang membayangkan bahawa dia adalah bebas untuk menerima atau menolak pesan al-Qur'an: penguatan-ulang yang lanjut tentang perintah al-Qur'an bahawa "tidak harus ada paksaan dalam urusan mengenai agama" (2:256)." 27

\section{IJTIHAD}

"Kerana kalau jiwa itu berhenti meninjau soal-soal atau berhenti berfikir, atau kurang perhatiannya kepada masalah-masalah yang mendalam, dia menjadi membeku, menjadi bodoh" - Ibn Maskawayh ${ }^{28}$

Dalam menegakkan prinsip hukum dan syariat, Asad menekankan keperluan peranan akal dan penalaran yang kritis dan ijtihad bagi mengembangkan prinsip hukum bagi menegakkan maslahah yang terhasil dari daya pemahaman terhadap keterangan nas:

"The Law-Giver meant us Muslims to provide for the necessary, additional legislation through the exercise of our ijtibad (independent reasoning) in consonance with the spirit of Islam." ${ }^{29}$

Kerana permasalahan hukum dan fatwa ini dapat dirungkai dengan pandangan ijma' yang kritis yang digarap dari dasar ijtihad dan ikhtilaf fiqhiyah yang memungkinkan percambahan dan pemugaran idea dan pemahaman teks yang berkesan:

"True progress is not possible without a variety of opinions, for it is only through the friction of variously constituted intellects and through the stimulating effect they have on one another that social problems are gradually clarified and thus brought within the range of solution." 30

\section{PERSPEKTIF ASAD TENTANG SYARIAT DALAM TAFSIRNYA}

"The more I understood concreteness and practicality of the Islamic

\footnotetext{
${ }^{27}$ Muhammad Asad, The Message of the Qur'an (Gibraltar: Dar al-Andalus, 1980).

${ }^{28}$ Hamka, Lembaga Budi (Batu Caves: PTS, 2017), 19.

${ }_{29}$ Muhammad Asad, The Principles of State and Government in Islam (Berkeley and Los Angeles, California: University of California Press, 1961), 14.

30 Muhammad Asad, The Principles of State and Government in Islam; 48.
} 
doctrine, the more I was tormented by a question why Muslims stopped to use them, apply them in life" ${ }^{31}$

[Semakin saya memahami keutuhan dan kebolehpakaian doktrin Islam, semakin saya terbimpit oleh persoalan mengapa umat Islam berhenti dari menggunakannya, menerapkannya dalam kehidupan]

Pandangan hukum Muhammad Asad dan penelitiannya tentang mazhab dan pemikiran fiqh dan syariat banyak diungkapkan dalam tafsirnya The Message of the Qur'an. Ia melakarkan pandangan hukum yang berakar dari tradisi pemikiran dan ijtihad yang menzahirkan aspirasi fiqh dan maqasid yang mendasar. Pandangan dan penghujahan hukum dan ketinggian ijtihadnya tentang idealisme syariat ini dizahirkan dalam komentarnya yang ekstensif pada surah al-Maidah ayat 38 (5: 38), yang memperlihatkan keluasan jangkauan fiqh dan ijtihadnya tentang syariat: [Adapun bagi lelaki yang mencuri dan wanita yang mencuri, potonglah tangan kedua mereka sebagai pembalasan terhadap apa yang mereka telah lakukan, sebagai suatu cegahan yang ditentukan oleh Tuhan]

Dalam tafsirnya, Asad menyebut: [Kekerasan yang bukan kepalang dari hukuman al-Qur'an ini dapat difahami hanya jika seseorang ingat prinsip yang fundamental dari Undang-Undang Islam bahawa tiada tugas (taklif) yang pernah dipikulkan kepada manusia tanpa dia dianugerahkan hak (baqq) yang sejajar; dan istilah "tugas" juga mengandungi, dalam konteks ini, kepertanggungjawaban kepada hukuman. Sekarang, antara hak-hak yang tak terpisah dari setiap anggota masyarakat Islam - Muslim dan bukan Muslim dengan setara - adalah hak untuk diberi perlindungan (dalam segenap pemahaman dari perkataan ini) oleh masyarakat secara keseluruhan. Sebagaimana terbukti dari pelbagai ketetapan al-Qur'an dan juga perintah Nabi (saw) yang didapat dari Hadith-Hadith yang sahih, setiap warganegara adalah berhak kepada habuan dari sumberdaya ekonomi masyarakat dan, justeru, kepada hak menikmati keselamatan sosial: dalam perkataan lain, dia harus terjamin dengan standard kehidupan yang wajar setimpal dengan sumber yang ada pada masyarakat.

Kerana, walaupun al-Qur'an menjadikannya jelas bahawa kehidupan manusia tidak dapat diekspresikan dalam kewujudan fizikal semata - nilai yang terakhir dari kehidupan adalah spiritual secara naturnya - orang-orang beriman tidak berhak untuk melihat kepada

${ }^{31}$ Muhammad Asad, Islam at the Crossroads (Kuala Lumpur: Other Press, 1999). 
kebenaran dan nilai spiritual sebagai sesuatu yang dapat dipisahkan dari faktor fizikal dan sosial dari kewujudan manusia.

Pendeknya, Islam membayangkan dan menuntut suatu masyarakat yang menyediakan tidak hanya kepada keperluan spirituil manusia, tetapi kepada keperluan tubuh dan inteleknya juga. Ia mengikuti, dengan itu, bahawa - untuk menjadi benar-benar islamik - suatu masyarakat (atau negara) harus dibentuk di mana setiap individu, lelaki dan wanita, dapat menikmati habuan minimum dari kesejahteraan materi dan keselamatan yang tanpanya tidak akan ada kehormatan manusia, tiada kebebasan yang sebenar dan, pada akibat yang terakhir, tiada kemajuan spiritual: kerana, tidak akan ada kebahagiaan yang sebenar dan kekuatan dalam suatu masyarakat yang mengizinkan sebahagian dari anggotanya untuk menanggung kemiskinan yang tak sepatutnya sementara yang lain punyai lebih dari yang mereka perlukan.

Jika seluruh masyarakat menanggung kekurangan disebabkan keadaan yang di luar kawalannya (sebagaimana terjadi, sebagai contoh, kepada masyarakat Islam pada hari-hari terawal Islam), kekurangan yang dikongsi itu mungkin menjadi sumber dari kekuatan spiritual dan, melaluinya, terhadap kebesaran masa depan.

Tetapi jika sumber yang ada dari masyarakat begitu tak sekata diagihkan di mana segelintir kelompok di dalamnya hidup dalam kekayaan sementara majoriti dari manusia dipaksa untuk mengerahkan seluruh tenaga mereka dalam mencari roti harian mereka, kemiskinan menjadi 'musuh yang paling merbahaya dari pembangunan spiritual, dan kadangkala membawa seluruh masyarakat jauh dari kesedaran padaTuhan dan kepada senjata dari materialisme yang menghancurkan-jiwa.

Tidak syak inilah yang Nabi (saw) fikirkan ketika Baginda (saw) mengungkapkan peringatan (dinukil oleh As-Suyuti dalam Al-Jami' asSaghir), 'Kemiskinan mungkin membawa kepada penafian terhadap kebenaran (kufr)." Alhasil, peraturan sosial Islam mengarah pada keadaan di mana setiap lelaki, wanita dan kanak-kanak mempunyai (a) cukup makan dan pakai, (b) rumah yang memadai (c) kemudahan dan peluang yang sama kepada pendidikan, (d) perawatan percuma dalam waktu sihat dan sakit. Akibat yang wajar dari hak-hak ini adalah hak kepada pekerjaan yang produktif dan lumayan ketika dalam usia bekerja dan kesihatan yang baik, dan peruntukan (oleh masyarakat atau negara) dari makanan yang cukup, tempat berlindung, etc. jika kehilangan upaya berakibat daripada penyakit, menjadi janda, dibuang kerja, usia tua, atau di bawah-umur. 
Sebagaimana telah disebutkan, kewajipan masyarakat untuk mewujudkan pelan keselamatan sosial yang komprehensif itu telah ditetapkan dalam banyak ayat-ayat al-Qur'an, dan telah diperkuatkan dan diperjelas oleh banyak pengarahan Nabi (saw). Ia adalah Khalifah kedua, 'Umar ibn al-Khattab, yang mula menterjemahkan ketetapan ini ke dalam pelan pentadbiran yang konkrit (lihat Ibn Saad, Tabaqat III/ 1, 213217); tetapi setelah kematiannya yang terburu, penerusnya tidak punyai wawasan atau kecakapan sebagai negarawan untuk melanjutkan kerjanya yang belum selesai. Ia adalah berlatarbelakangkan pelan keselamatan sosial yang dibayangkan Islam ini bahawa al-Qur'an mengenakan hukuman yang keras dengan pemotongan-tangan sebagai hukuman pencegah terhadap perampokan.

Kerana, di bawah keadaan yang digariskan di atas, "godaan" tidak dapat diterima sebagai alasan yang absah, dan kerana, dalam pilihan terakhir, seluruh sistem sosio-ekonomi Islam adalah berlandas kepada keimanan dari penganutnya, keseimbangannya adalah sangat rumit dan perlukan perlindungan yang berterusan, dikuatkuasakan dengan ketat. Dalam suatu masyarakat di mana setiap orang dijamin keselamatan yang penuh dan keadilan sosial, sebarang percubaan untuk di pihak individu untuk mencapai keuntungan yang mudah, tak berasas dengan mengorbankan anggota yang lain dari masyarakat harus dianggap sebagai serangan terhadap sistem itu secara keseluruhan, dan harus dihukum dengan sendirinya: dan, kerana itu, ordinan di atas yang menetapkan bahawa tangan pencuri harus dipotong. Seseorang harus, bagaimanapun, sentiasa ingat prinsip yang diungkapkan pada permulaan nota ini: yakni, kebergantungan yang mutlak antara hak-hak manusia dan tugas yang sejajar (termasuk kebertanggungjawaban kepada hukuman). Dalam suatu masyarakat atau negara yang mengabaikan atau tidak mampu untuk menjamin keselamatan sosial yang sempurna ke atas semua anggotanya, kecondongan untuk memperkayakan diri sendiri secara haram menjadi tak tertepis - dan, alhasil, pencurian tidak harus dihukum sekeras sebagaimana ia harus dihukum dalam negara di mana keselamatan sosial adalah suatu realiti dalam maksud perkataan ini yang sepenuhnya.

Jika masyarakat tidak mampu untuk memenuhi tanggungjawabnya terhadap setiap seorang daripada anggotanya, ia tidak mempunyai hak untuk menuntut hukuman yang sepenuhnya dari undang-undang jenayah (badd) ke atas pelanggar hukum, tetapi harus membataskan dirinya kepada bentuk hukum administrasi yang lebih ringan. (Hal ini adalah dengan penghayatan yang tepat terhadap prinsip ini bahawa Khalifah 'Umar melepaskan hadd potong-tangan dalam zaman kebuluran yang 
melanda jazirah Arab ketika pemerintahannya.) Untuk merumuskan, seseorang dapat dengan selamat menyimpulkan bahawa pemotongan tangan sebagai hukuman terhadap perampokan adalah terpakai hanya di dalam konteks pelan keselamatan sosial yang sudah-sedia ada, sepenuhnya berfungsi, dan bukan dalam keadaan yang lain." ${ }^{32}$

Dan prinsip hukum dan idealisme syariat yang dikutip dari pandangan Ibn Hazm yang menggariskan pemikiran asas syariat dan falsafahnya yang ideal dan perbandingannya dengan mazhab pemikiran dan tafsiran al-Razi, Baghawi, Zamakhshari dalam tafsiran ayat: "DAN ATAS APA SAJA yang kamu perselisihkan, [Wahai orang-orang beriman,] keputusannya adalah tertakluk kepada Tuhan.” (42:10)

Asad menguraikan: "Ini, berkait dengan kalimat pertama dari ayat 8 di atas (Adapun jika Tuhan menghendaki, Dia dapat sesungguhnya menjadikan mereka seluruhnya umat yang satu), jelas berhubung dengan masalah tentang iman dan syariat agama (Baghawi, Zamakhshari). Ayat di atas telah menelantarkan kepada beberapa eksponen besar syariat Islam Ibn Hazm antara mereka - dengan satu dari hujah utama dalam menolak istinbat dengan analogi (qiyas) sebagai kaedah untuk "menegakkan" dasar dari syariat yang tidak dirumuskan sendiri dalam nass - i.e., pernyataan yang terbukti-sendiri (zahir) dari al-Qur'an dan, dengan implikasi yang jelas, dari perintah Nabi (saw). Ini, sebagaimana Razi tunjukkan, adalah maksud dari frasa "atas apa saja yang kamu perselisihkan, keputusan (bukm) nya adalah tertakluk kepada Tuhan". (Lihat dalam hubungan ini nota 120 pada 5:101; juga bahagian tentang "Skop Perundangan Islam" dalam tulisan saya State and Government, hh. 11-15.) ${ }^{3.3}$

\section{Politik dan Syariat}

There is not only one form of the Islamic state, but many; and it is for the Muslims of every period to discover the form most suitable to their needs - on the condition, of course, that the form and the institutions they choose are in full agreement with the explicit, unequivocal shariah laws relating to communal life." 34

\footnotetext{
${ }^{32}$ Muhammad Asad, The Message of the Qur'an (Gibraltar: Dar al-Andalus, 1980), 5:38.

${ }^{33}$ Muhammad Asad, The Message of the Qur'an (Gibraltar: Dar al-Andalus, 1980), 5:101, ft. 120, dan Muhammad Asad, The Principles of State and Government in Islam (Berkeley and Los Angeles, California: University of California Press, 1961), 11-15.

34 Muhammad Asad, The Principles of State and Government in Islam; 23.
} 
Kefahaman Muhammad Asad tentang syariat ini turut berkait dengan pandangan dan idea politiknya yang dinamik dan moden. Dalam bukunya The Principles of State and Government in Islam, Asad menggariskan dasar dan prinsip negara yang dirumuskan dari nas dan tradisi al-Qur'an dan Sunnah, di mana beliau menggariskan dua batas penentu, i.e., dalam negara Islam kedaulatan yang sebenar terletak pada Tuhan dan bahawa orang-orang beriman harus menyelenggarakan semua urusan menyangkut dengan negara dan masyarakat melalui musyawarah. Dalam rangka ini, Asad menunjukkan bahawa negara Islam dapat mengambil bentuk dari sebuah demokrasi berparlimen dan negara hukum, termasuk institusi moden dari sistem kepresidenan dan Mahkamah Agung, seperti dirumuskan dalam karyanya:

"A state inhabited predominantly or even entirely by Muslims is not necessarily synonymous with an "Islamic state": it can become truly Islamic only by virtue of a conscious application of the sociopolitical tenets of Islam to the life of the nation, and by an incorporation of those tenets in the basic constitution of the country." 35

Menurutnya, kerangka dan prinsip dasar yang dibangunkan harus ditegakkan dari asas politik yang kuat yang menetapkan ideologi Islam yang fundamental yang memungkinkan terbangunnya sistem yang bebas dan berkesan dalam pengerahan jentera kerajaan dan perundangan dan penguatkuasaan undang-undang dalam kerajaan:

"It is only within the framework of an independent ideological state built on the principles of Islam and endowed with all the machinery of government, legislation, and law-enforcement that the ideals of Islam can be brought to practical fruition." 36

Beliau melakarkan dasar yang jelas tentang faham politik dan pandangan budaya dan sosial yang dinamik, dengan menggariskan prinsip musawah, 'adalah, amānah, mas-uliyyah, dan hurriyah berlatarkan faham musyawarah Islam, di mana "human ingenuity has not evolved a better method for corporate decisions than the majority principle." ${ }^{37}$

Hujahnya tentang prinsip kebebasan ini turut diperkukuh dalam huraiannya pada frasa shura baynabum ("perundingan sesama mereka") dari ayat 38, surah al-shura yang menggariskan satu dari prinsip sosial

\footnotetext{
35 Ibid; 1.

36 Ibid; 96.

37 Ibid; 50.
} 
yang mendasar yang harus mencorakkan ciri masyarakat mukmin yang sebenar."

(38) dan yang menyahut [seruan dari] Tuhan mereka dan istiqamah dalam sembahyang; dan yang keputusannya [dalam semua perkara tentang maslahat umum] adalah perundingan sesama mereka

"Kualifikasi yang khusus pada mukmin yang sebenar ini - dianggap oleh para Sahabat Nabi (saw) sebagai begitu penting di mana mereka sering merujuk kepada surah ini dengan kata-kunci "musyawarah" (shura) mempunyai dua lapis maksud: pertama, ia bermaksud untuk mengingatkan semua pengikut al-Qur'an bahawa mereka harus terus berserikat dalam jamaah umat yang satu (ummah); dan kedua, ia menggariskan prinsip bahawa semua urusan masyarakat harus disempurnakan melalui perundingan. (Bagi implikasi politik dari prinsip ini, lihat State and Government, hh. 44 ff.) ${ }^{38}$

\section{Kesimpulan}

"The Shariah is made for man, not man for the Shariah" 39

(Shariah dibentuk untuk manusia, bukan sebaliknya)

Muhammad Asad telah memperlihatkan kefahaman fiqh dan syariat yang mendasar dari perbincangan yang meluas tentang soal-soal hukum dan fiqh Islam. Tulisannya melakarkan falsafah pemikiran hukum dan menghuraikan ruang lingkup dan implikasi syariah yang mendasar.

Penelitiannya tentang hukum ini menyangkut tentang prinsip maqasid dan idealismenya yang meluas, yang digarap dari kerangka pemikiran hukum yang menyeluruh dan praktik budaya dan masyarakat dan pesan syar'i yang diungkapkan dalam al-Qur'an. Ia mengangkat nilai Islam yang universal dan menjelaskan fikrah syariah dan nilai maqasid yang ideal. Ini diperlihatkan dalam tafsiran ayat-ayat al-Qur'an seputar prinsip hukum dan idealisme syariah dalam usahanya untuk mengembangkan ideologi Islam yang rasional dan dan menyuguhkan pandangan dan faham humanisnya.

\section{Daftar Pustaka}

\footnotetext{
38 Ibid; $44 \mathrm{ft}$.

${ }^{39}$ Mustafa Akyol, Islam Without Extremes: A Muslim Case for Liberty (New York: W.W. Norton \& Company, Inc., 2011).
} 
Al-Attas, Syed Muhammad Naquib, Islam: Faham Agama dan Asas Akhlak (Kuala Lumpur: Yayasan Anda Akademik, 1977).

Al-Tabari, Jami' al-Bayan 'an Ta'wil Ay al-Qur'an (Bayrut: Dar Ihya' alTurath al-'Arabi, 2001).

Hamka, Hak Asasi Manusia dalam Islam dan Deklarasi PBB (Shah Alam: Pustaka Dini, 2002).

Hamka, Lembaga Budi (Batu Caves: PTS, 2017).

Muhammad Arshad, "Muhammad Asad: Twenty-Six Unpublished Letters" dalam Islamic Science, Vol. 14 (Summer, No. 1, 2016), 25- 66.

Muhammad Asad, Melalui Dua Simpang Jalan, terj. Ahmad Ibrahim (Singapura: KB Press, 1948).

Muhammad Asad, The Principles of State and Government in Islam (Berkeley and Los Angeles, California: University of California Press, 1961).

Muhammad Asad, The Message of the Qur'an (Gibraltar: Dar alAndalus, 1980).

Muhammad Asad, This Law of Ours and Other Essays (Kuala Lumpur: Islamic Book Trust, 1987).

Muhammad Asad, Islam at the Crossroads (Kuala Lumpur: Other Press, 1999).

Muhammad Asad, Jalan ke Makkah, terj. Fuad Hashem (Jakarta: Pustaka Mizan, 2002).

Muhammad Asad, Sahih al-Bukhari: The Early Years of Islam (Kuala Lumpur: Islamic Book Trust, 2002).

Muhammad Asad, "Social and Cultural Realities of the Sunnah", dalam

P.K. Koya (ed.), Hadith and Sunnah: Ideals and Realities (Kuala Lumpur: Islamic Book Trust, 2003), 233-250.

Mustafa Akyol, Islam Without Extremes: A Muslim Case for Liberty

(New York: W.W. Norton \& Company, Inc., 2011).

Muzaffar Iqbal, "The Making of A Free Thinker in Islam (Part I)

Muhammad Asad: The Pakistan Years" dalam Islamic Science,

Vol. 14 (Summer, No. 1, 2016), 3-24.

Pipip Ahmad Rifai Hasan, "The Political Thought of Muhammad Asad"

(M.A. Thesis - Department of Religion, Concordia University Montreal, Quebec, Canada, 1998).

Rahimah Embong, Mohamad Zaidin Mat@ Mohamad, Siti Fatimah Mohd, "A Critical Analysis of Muhammad Asad's Thoughts on Islamic Civilization" dalam Proceedings, International Conference on Empowering Islamic Civilization in the 21st Century (Universiti Sultan Zainal Abidin Malaysia, 6-7 September, 2015). 
Showkat Ahmad Dar, "Muhammad Asad's Approach to Shari'ah: An Exposition" dalam Journal of Islamic Thought and Civilization, vol. 5 (Issue II (Fall) (2015), 15-23.

Siti Fatimah Mohd, Rahimah Embong, "Challenges of Islamic Civilization and Its Implications: A Critical Analysis from Muhammad Asad's Points of View" dalam Proceedings, World Islamic Social Science Congress (1st WISSC 2015) (Universiti Sultan Zainal Abidin, 1-2 December, 2017).

Tariq Ramadan, "A Tribute to Muhammad Asad" Keynote Lecture (Securities Commission, Mont Kiara, Kuala Lumpur, 13 December, 2009). 